MICA.

\title{
By Theo. D. Raxd.
}

Of commonly occurring minerals, few are more remarkable than those of the mica family. Originally, the word mica was applied to a variety of minerals closely resembling each other, then supposed to be identical, but which the advance of science has shown to be distinct species, so that now the term is applied to a large class of minerals, the distinguishing characteristic of which is their readily splitting into thin laminæ.

Common mica, or Muscovite, is very abundant in most of the older rocks, it being a constituent of gneiss, granite and micaschist.

It splits into thin laminæ, or leaves, very readily. This is due to cleavage, or the property, possessed by most crystalline substances, of breaking most readily in certain planes, which bear a relation to the axes of the crystals. For instance, take a crystal, or fragment of a crystal, of galena, or of rock salt; break it into small pieces, and these, if you will, again and again, even until a microscope is needed to see the form of the grains; nearly all the fragments, large and small, will be found to be rectangular in shape, or with sides parallel to the faces of a cube, the crystals dividing readily into that form, and into no other. If fluor spar be treated in like manner, the surfaces of its fragments will be found to be parallel to the faces of an octahedron. A crystal of common feldspar, or orthoclase, similarly treated, will give rectangular cleavages on four sides, but the remaining sides will, in almost all specimens, be found to be wholly destitute of cleavage, and to break with difficulty, and irregularly. The readiness with which the specimens will cleave will be found to differ. 'The galena breaks with great ease into perfectly rectimgular blocks, with smooth and shining surfaces, the salt likewise, but less easily; the fluor spar breaks still less readily, and more care is required to obtain a smooth surface; the feldspar breaks with great ease in one direction, and with much less ease in the other at right angles. These examples will help us to understand the cleavage of mica. It (generally) cleaves in one direction only, but in that direction its cleavage is almost perfect, and very easy indeed. To this property, and to the fact that it is unaltered 
by a moderate heat, is due its large use for doors for stoves, etc., for closing the eye holes of blast furnaces, and other similar purposes. Occasionally a second cleavage exists, and when this is the case the result is long fibres almost hair-like in appearance.

Chemically, mica is a silicate of alumina and potash with a small amount of iron, magnesia and soda, and usually from one to five per cent. of water.

Another remarkable property of mica is its great elasticity and toughness. It is equaled in these respects by very few materials, and in the combination of the two it is probably excelled by nothing natural or artificial.

Granite is composed of crystals, or crystalline masses, of mica, quartz and feldspar; sometimes the crystals or masses are very small, as in common granite; sometimes very large, and when so, the mica becomes valuable; the granite is a "mica mine."

Formerly, nearly all the mica used in the United States came from Russia, whence crystals over a yard in diameter are said to have been procured; but now several mines are, and have been wrought in the United States, especially at Grafton, N. H., and in Western North Carolina.

A large amount of mica was obtained from an opening in the southern part of Chester county, Pa., not far from the celebrated Dixon's quarry. It occurred in a granite vein, in which, as is very commonly the case, the feldspar had become wholly decomposed into clay, leaving the quartz and mica unaltered. The vein was followed nearly vertically some forty or fifty feet. Crystals of mica over two feet across and weighing over a hundred pounds were obtained, much of it of excellent quality, but some of it rendered nearly opaque by dendrites of magnetic iron between the films of the mica, rendering it useless for stove purposes, but forming cabinet specimens of great beanty. The quarry, which gave promise of considerable vield (properly wrought), was neglected, until the sides of the excavation caving in, it was abandoned.

As we have stated, the varieties of mica, now distinguished ly mineralogists, are numerous - the most common after muscovite are:

Biotite, generally of a dark color-the black mica so abundant in many granitic and gneissic rocks.

Lepidomelane; black, and not distinctly separated from biotite. 
Phlogophite; generally brown or red-the mica occurring in limestones.

Lepidolite; a red or pink mica containing the rare earth lithia.

Mica, like most other minerals, is found to change by long exposure to atmospheric influences, but the muscovite seems least susceptible tosuch decomposition, and to lee more stable than the feldspar which usually accompanies it,- - there results a micaceous soil, so common in some parts of our country, as in Philadelphia. Often such mica becomes red and yellow in color, probably from oxide of iron, and the instances are numerous in which it has been mistaken for gold. It is believed that the class of minerals known as the vermiculites have resulted from an alteration of mica, chiefly by the absorption of water. These are characterized by a very great and powerful expansion when heated. This expansion increases the bulk enormously, and the force is sufficient to break a test tube if the mineral be heated in it.

Mica ground in a mill increases vastly in bulk and forms a loose light mass of scales not unlike bran. It is largely used in this form in the so-called mica powder as an absorbent of nitroglycerine, its peculiar elasticity rendering accidental explosion by percussion almost impossible, while it does not interfere with the energy of the nitroglycerine when exploded by a fulminate or other similar device.

To the microscopist a world of interest may be found in the micas. They frequently contain, between the layers, microscopic erystals of minerals, some of them, especially with polarized light, forming specimens of wonderful beauty. Of most minerals, sections for microscopicexamination must be made by the laborious process of grinding and polishing, but in mica we may almost say the sections are made by nature, and the time required to make one section of most minerals will make at least a hundred of mica, and the thickness or thinness is a matter of perfect control.

Perhaps the richest mica in these crystals, at least in variety, is that from the locality mentioned in Chester county, Pa. Most abundant is magnetite, or magnetic iron, usually in beautiful arborescent forms, black in color, but sometimes, probably owing to a change into. limonite or gothite, various shades of yellow. Quartz crystals, generally flattened, sometimes perfect, are not uncommon, and form, with polarized light, specimens more brilliant than any other mineral. Besides these, various other forms occur, the identification of which with known species has not yet been accomplished.-Science Adrocate. 